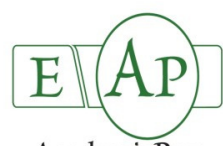

AcademicPres

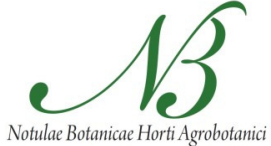

Cluj-Napoca

\title{
Tilia spp. - Urban Trees for Future
}

\author{
Alina M. ŢENCHE-CONSTANTINESCU ${ }^{1}$, Emilian MADOŞA ${ }^{1}$, Dănuț CHIRA ${ }^{3}$, \\ Cornelia HERNEA ${ }^{1}$, Radu V. T,ENCHE-CONSTANTINESCU², \\ Dacian LALESCU ${ }^{4}$, Gheorghe F. BORLEA ${ }^{2 *}$
}

\author{
'Banat's University of Agricultural Sciences and Veterinary Medicine "King Michael I of Romania" from Timisoara, Faculty of Horticulture and Forestry, \\ 109Calea_Aradului,Timisoara,Romania; consta_alina@yahoo.com,madosae@yahoo.com,corneliahernea@usab-tm.ro \\ ${ }^{2}$ Banat's University of Agricultural Sciences and Veterinary Medicine "King Michael I of Romania" from Timişoara, Faculty of Agriculture, \\ 109 Calea Aradului,Timişoara,Romania; fborlea@yahoo.com (*correspondingauthor),radutenche@yahoo.com \\ ${ }^{3}$ Forest Research and Management Institute, Bucharest,Brasov Branch,26Closca, Brasov, Romania; chira@dsbv.ro \\ ${ }^{4}$ Banat's University of Agricultural Sciences and Veterinary Medicine "King Michael I of Romania" from Timişoara, Faculty of Food Processing Technology, \\ 109 Calea Aradului, 300645 Timişoara, Romania; dlalescu@yahoo.com
}

\begin{abstract}
Tilia spp. (lime trees) as ornamental trees have a privileged place in the European mythology and traditions and this is a reason of their constant presence in the urban landscape. Lime trees are in general very resistant to biotic and abiotic stress, although some sanitary problems may occur (e.g. aphids and other related organisms). Tilia spp. are considered a good bioindicator and accumulator of heavy metals. Seasonal accumulations of $\mathrm{Pb}, \mathrm{Ni}, \mathrm{Cr}, \mathrm{Mn}, \mathrm{Cu}$ and $\mathrm{Fe}$ in leaves of Tilia spp. in urban and periurban green areas of Western Romania, under different traffic conditions, were analyzed using atomic absorption spectrophotometry. The results confirmed the direct correlation between the traffic intensity and the accumulation of $\mathrm{Pb}$ in leaves. By mitigating the effects of air pollution, especially in terms of heavy metals, Tilia spp. should be further promoted as urban trees.
\end{abstract}

Keywords: bioaccumulator, bioindicator, climate change, heavy metals, seasonal accumulation

\section{Introduction}

Urban trees play an important role in the urban living space, by bringing social benefits, improving environmental quality (e.g. removing PM10 from urban air) and also contributing to local identity (McDonald et al., 2007; Nowak, 2007). One of the most common urban trees is the Lime tree (Tilia spp.), both native species and ornamental varieties. Out of 40 genera and over 350 species of the Tiliaceae family that are to be found especially in the tropical and subtropical regions, in Romania the lime trees are represented by a single genus (Tilia) with three species: Tilia cordata Mill. (the most common), T. tomentosa Moench. (the most drought tolerant), and T. platyphyllos Scop. (the most water demanding). Of all trees that tradition invested with special virtues, the lime tree holds a special place both in the Romanian (Eliade, 1995) and in the European imagery (Radouglu et al., 2009) due to its numerous uses and symbols: the sacred tree of Aphrodite in
Greek mythology or the sacred tree of the fertility goddess Freia in German mythology (Evseev, 2001), a sacred tree in slavic mythology (Blench and Spriggs, 1999), a national symbol in Slovakia, Slovenia and the Czech Republic (Snoj, 2009). In the Romanian imagery, the lime tree is a constant presence in the traditions related to religious celebrations (Eliade, 1995) and also the most frequently mentioned tree in the poems, songs and stories.

The potential use of Tilia spp. as ornamental urban trees and as medicinal plants is well known in all regions of Europe (Ivănescu et al., 1966; Şofletea and Curtu, 2007; Soukand et al., 2013). The air in urban and periurban areas has been polluted with numerous solid and liquid particles in suspension that vary in size, morphology and chemical composition. The Tilia spp. leaves have showed significant seasonal accumulation especially for $\mathrm{Pb}$ but also for $\mathrm{Cr}, \mathrm{Fe}$, $\mathrm{Ni}, \mathrm{Zn}$ and Mn (Bargagli, 1998; Piczak et al., 2003; Tomaševic et al., 2004b; Anicic et al., 2011). The aim of this 
260

paper was to provide arguments in order to promote Tilia spp. as urban trees by analyzing their social role and their potential as ornamental trees, bioindicators and heavy metal bioaccumulators $(\mathrm{Pb})$.

\section{Materials and methods}

Firstly, a literature review has been performed on ornamental role, current health issues, potential use as pollution bioindicator and heavy metal bioaccumulation aspects.

Secondly, the seasonal accumulation of heavy metals in Tilia spp. leaves in Western Romania (Timisoara region) has been analyzed. In order to study heavy metal accumulation, samples (minimum $30 \mathrm{~g}$ of leaves) have been collected from individuals (11-14 years old) of Tilia genus, in street alignments, in locations with different pollution intensity levels: no traffic (Căvăran Forest T. tomentosa and Borlova Forest - T. platyphyllos); low traffic (urban area in Timişoara, Albinelor Street - T. cordata, $T$. tomentosa, T. platyphyllos and rural area Borlova - T. platyphyllos, $T$. cordata); medium traffic (urban area Timişoara - I. I. de la Brad Street - T. cordata); heavy traffic (road to Timişoara Airport $-T$. tomentosa). Samples were encoded as follows: species (C $-T$. cordata; P - T. platyphyllos; T - T. tomentosa); locations (AL Albinelor Street, Timişoara; II - I. I. de la Brad Street, Timişoara; AR - Airport, Timişoara; M - Borlova Forest; B - Borlova village; C - Căvăran Forest); sampling data (M - May; A - August).

The representativeness in both the sampling design and the chemical analyses procedure was ensured. Thus, two sampling operations were performed: in May (average size fresh leaves) and in August (average size mature leaves, before the autumn senescence). Samples were collected during the same week from 10 individuals/location, in three repetitions/individual ( 90 average size leaves). The leaves were collected from the south-facing upper part of the outer tree canopy and numbered (location, data, species, age). Leaves from the outer canopy accumulate more particles due to the higher transpiration rates (Bargagli, 1998). Random chosen 30 g leaves/individual were washed for 25 seconds with deionized water $(\mathrm{pH}=5.8-5.9)$.

The samples were dried at $105^{\circ} \mathrm{C}$ for 24 hours. $1-5 \mathrm{~g}$ of samples were mixed twice with $5 \mathrm{ml}$ of nitric acid (65\%) and the mixture was brought to $80^{\circ} \mathrm{C}$ twice (about $2 \mathrm{~h}$ ) until completely dried. $5 \mathrm{ml}$ of de-ionized water was added and the suspension was filtered through special paper filter $(180 \mathrm{~mm}$ thick, with pores of 20-25 $\mu \mathrm{m}$ ). The quantity of de-ionized water was increased up to $50 \mathrm{ml}$ and heavy metal concentrations were measured during the atomic absorption with the spectrophotometer VARIAN 220 FAA. The recordings were performed after the calibration for each microelement, at the following wavelength: $\mathrm{Cu} 324.7 \mathrm{~nm}, \mathrm{Fe}$ 259.9 nm, Cr205.5 nm, Ni231.6nm, Pb $220.3 \mathrm{~nm}$.

The variance analysis and the post-hoc Duncan test of multiple comparisons were performed in order to compare the $\mathrm{Pb}$ concentrations recorded in the samples for each species, location and time of sampling. All calculations were done using Statistica 10 software.

\section{Results and discussions}

\section{Tilia spp. as ornamental trees}

Due to their special shape, Tilia spp. are used as main elements in designing grandiose and inspiring green areas. The beauty of these species all the year round is underlined by associating Tilia spp. with different ornamental shrubs in order to get perspectives focused upon Tilia spp. on coniferous background. Combinations in green areas with different species and varieties of Tilia spp, which blossom successively, are highly appreciated because of a longer period with flowers and fragrance. Some authors described hybrids (Ivănescu et al., 1966; Fricke et al., 1980), other authors reported new species (Zare et al., 2012) and others considered that genuine inter-specific hybrids are extremely rare (Neville-Jones, 1968). However, molecular markers can be applied to characterize hybridization and species differentiation in Tilia genus (Fineschi et al., 2003).

Tilia spp. produce a large number of sprouts with larger diameters and heights (Matula et al., 2012) and show no decline in sprouting vigour with age (Pigott, 1991). T. cordata leaves may represent a reliable indicator for evaluation studies on developmental stability based on the ability of its leaf morphometric characters to buffer their development under contrasting environmental conditions (Velikovic, 2010). The difference in the morphology of the crown as well as in the leaf structure seems to be an advantage for Tilia spp. when compared with other popular urban trees in Central Europe, considering the influence on air flow, deposition of air-borne particles, abatement of wind speed, reducing building energy use by lowering temperatures and shading buildings during the summer (Nowak, 2006). Sjöman and Oprea (2010) reported that $T$. tomentosa, $T$. cordata and $T$. vulgaris show long-lasting health and hardiness in street environments of Northern Europe.

In the system of green spaces in Timişoara, the global valuation method of the trees was applied by Ciupa et al. (2005), by using three components: ecological value, landscape value (general physiognomy of the species shape, individual size, subjectivity of the observer) and vitality; the results indicated Tilia spp. as the most valuable trees in this context. Different authors mentioned the high landscape value of Tilia spp. (Ivănescu et al., 1966; Neville-Jones, 1968; Jensen, 2003; Sjöman et al., 2012; Halajová and Halaj P, 2013). Remarkably old trees as well as the young ones are very common in parks and street alignments in Romania, both in groups and as isolated individuals, mainly in residential areas where citizens decide what species to be planted.

\section{Tilia spp. resistance to biotic and abiotic factors}

Climate change seems to increase the frequency of extreme events. In Romania, severe drought (1999-2000, 2003, 20112012) alternated with flooding $(2005,2010)$ and severe frost (2012) with milder winters (2013-2014). Tilia spp. seems to be more resistant to drought compared to other native tree species (Simionescu et al., 2012). T. cordata and T. platyphyllos showed sensitivity to backwater (3 months) and to very poor land drainage conditions (Dănescu et al., 2011).

Aphids and other related organisms, such as plant lice and mites, are strongly related to Tilia spp. in green areas but they only cause minor problems to the lime (Zuparko and Dahlsten 1994).

In flooded areas $(2005,2010,2014)$, lime tree collar and roots were relatively fast affected by rot and dieback. Phytophthora spp. were among the first organisms to damage the 
fine roots (Dănescu et al., 2011) and could lead to the death of the stressed plants.

Armillaria spp. proved to be aggressive opportunists only on weakened lime-trees in forests, being followed by Ganoderma lucidum and other root destroying fungi. On upper roots and stem of trees in urban areas, the wounded bark of old trees was frequently colonized by Schizophyllum commune (sapwood parasite), followed by xylofagus fungi: Stereum spp., Trametes spp. and Laetyporus sulphureus or other Polyporaceae which rot the stem and favour the wind breaks (Chira et al., 2000). Limetrees were the most resistant tree species to the biotic and abiotic factors in the decade 2001-2010 in Romanian forests (Simionescu et al., 2012), presenting only minor problems (e.g. only 120 acres defoliated by Caliroa anuplipes out of a total of infested 742,74ha).

\section{Tilia spp. as a biomonitor and bioaccumulator}

Trees play a special role in reducing the level of fine, "high risk" breathable particles with potential side effects on the environment and on human health (Beckett et al., 2000 from Aničić et al., 2011). Tree leaves have been widely used as an indicator of atmospheric pollution and they are an effective alternative to the usual biomonitoring methods (Braun $e t$ al., 2007). Tilia spp. is one of the best indicators of pollution (especially with chlorine), displaying clear spring (clorosis) and summer (necrosis) symptoms, in street alignments (Braşov, Romania) and industrial polluted areas (Dej, Romania) (Bolea and Chira, 2005).

Having an adequate morphology, canopy structure and epicuticular wax on the leaf surface, lime-trees have been used as suitable biomonitors of aerial trace elements in leaves in urban areas (T. tomentosa - Kovács and Podani, 1986; T. cordata Bargagli, 1998; Tilia tomentosa, Tilia cordata, Tilia platyphyllos - Braun et al., 2007). According to Jurani et al., 1993 (from Šomšak et al., 2007), T. cordata seems to be a better bioaccumulator of heavy metals than Acer platanoides. Different authors (Baycu et al., 2006; Popović et al., 2010; Oroian et al., 2012) reported that of the analyzed urban trees, A. hippocastanum accumulated the highest $\mathrm{Pb}$ concentrations in leaves and could be used as a monitor of concentrations and seasonal variations of heavy metals in air in urban areas. Recently, the use of plants as bioaccumulators or bioindicators has increased because it makes it possible to forecast air pollution for monitoring purposes.

A low-cost, practical method to assess the quality of the urban habitat consisted of determining the injured leaf area reflectance of Tilia spp. out of the leaf surface reflectance (Khavaninzadeh, 2014). The findings of many studies showed that metal accumulation in plants varied, depending on species, tissues and metals but it is obvious that Tilia spp. meet many of the requirements of a good bioindicator for heavy metals accumulation.

\section{Heavy metals accumulation in Tilia spp.}

There were significant differences $(p<0.05)$ between limetree species in $\mathrm{Cr}, \mathrm{Cu}, \mathrm{Fe}, \mathrm{Ni}$ content and non-significant differences in $\mathrm{Pb}$ and $\mathrm{Mn}$ content for leaves sampled in May
Table 1. Differences in heavy metals content after the seasonal accumulation (May-August, 2014) in Tilia spp.

\begin{tabular}{cccccc}
\hline Species & \multicolumn{5}{c}{ Heavy metals $(\mathrm{mg} / \mathrm{kg}$ of dry material) } \\
\cline { 2 - 6 } Locations $^{* *}$ & $\mathrm{Cr}$ & $\mathrm{Cu}$ & $\mathrm{Fe}$ & $\mathrm{Mn}$ & $\mathrm{Ni}$ \\
\hline $\mathrm{C} / \mathrm{AL}$ & -0.083 & -1.229 & 14.146 & -13.078 & -1.822 \\
$\mathrm{C} / \mathrm{II}$ & 0.017 & 0.031 & 30.284 & -19.291 & -1.916 \\
$\mathrm{~T} / \mathrm{AL}$ & -0.302 & -2.372 & -36.484 & -13.667 & -2.917 \\
$\mathrm{P} / \mathrm{AL}$ & -0.22 & -1.677 & -2.171 & -13.019 & -3.133 \\
$\mathrm{~T} / \mathrm{AR}$ & -0.01 & -1.824 & 62.075 & -22.947 & -0.248 \\
\hline
\end{tabular}

${ }^{*}$ Species $=\mathrm{C}-$ T. cordata $\mathrm{P}-$ T. platyphyllos $; \mathrm{T}-$ T. tomentosa;

${ }^{* *}$ Urban locations in Timisoara = AL - Albinelor Street; II - Ion Ionescu de la Brad Street; periurban location $=$ AR - Timişoara Airport

2014. When analyzing leaves sampled in August, the variance analysis showed significant differences between Tilia spp. in heavy metal accumulation except for $\mathrm{Fe}(\mathrm{p}=0.10)$ and $\mathrm{Ni}$ $(\mathrm{p}=0.07)$. Our study indicated that only $\mathrm{Pb}$ was accumulated by all individuals irrespective of species and locations. The other heavy metals did not show a regular pattern during the growing season (Table 1).

Some metals could be used as micronutrients $(\mathrm{Fe})$ or macronutrients $(\mathrm{Cu}, \mathrm{Zn})$ but generally, the interpretation of data related to accumulation of heavy metals from the air is difficult (Iordache, 2009). A continuous reduction of annual emissions of $\mathrm{Pb}$ has been recorded starting with 2009 in Timisoara. The highest heavy metal emissions were recorded for $\mathrm{Pb}, \mathrm{Zn}$ and $\mathrm{Ni}$, as coming mainly from fuel combustion (Romania, Timisoara Environment Protection Agency, 2014). The local soil was alkaline, $\mathrm{pH}>8.0$ (Tenche-Constantinescu, 2011) and this causes lower element solubility and lower availability for plants (Tomaševic et al., 2004a; Serbula et al., 2013). Pb solubility in soils with various conditions was very low (Adriano, 1986; Alloway, 1995) and terrestrial plants accumulated less $\mathrm{Pb}$ from soil than from the atmosphere through stomata and the accumulated quantity depended on air pollution, particle size and climate. Under such environmental conditions, the atmospheric origin of the elements accumulated in leaves may be assumed: Achillea millefolium and Hordeum vulgare (Pilegaard and Johnsen 1984), Quercus ilex (Alfani et al., 1996), Populus spp. (Gregger, 1999), Salix spp. (Iordache, 2009), Picea abies (Hovmand et al.,2009) and Tilia spp. (Serbula et al.,2013).

There were highly significant differences in $\mathrm{Pb}$ accumulation $(p<0.001)$ by comparing: all species under similar traffic conditions at the end of the growing season $(\mathrm{C} / \mathrm{AL} / \mathrm{A} ; \mathrm{P} / \mathrm{AL} / \mathrm{A}$; $\mathrm{T} / \mathrm{AL} / \mathrm{A}$ ); different species or individuals of the same species, under different traffic conditions and in the same sampling period and different species or individuals of the same species, under the same traffic conditions and at different moments of sampling (seasonal accumulation) (Table 2). Moreover, we found significant differences in $\mathrm{Pb}$ accumulation $(p<0.05)$ by comparing $T$. platyphyllos and $T$. cordata under different traffic conditions at the end of the growing season $(\mathrm{P} / \mathrm{B} / \mathrm{A} ; \mathrm{C} / \mathrm{II} / \mathrm{A})$. However, no significant differences in $\mathrm{Pb}$ accumulation $(p>0.05)$ were found when comparing species at the beginning of the growing season under different traffic conditions (C/AL/M; C/II/M; P/AL/M; T/AL/M; T/AR/M). The Pb accumulation in leaves at the beginning of the growing season was very low for all species and locations (minimum 0.01280 $\mathrm{mg} / \mathrm{kg} \mathrm{Pb}-\mathrm{T} / \mathrm{AR} / \mathrm{M}$ and maximum $0.3631 \mathrm{mg} / \mathrm{kg} \mathrm{Pb}$ $\mathrm{T} / \mathrm{AL} / \mathrm{M})$. 
262

There were highly significant differences in $\mathrm{Pb}$ accumulation among all species of lime-tree studied under similar traffic conditions (Albinelor Street, Timisoara) at the end of the growing season. The differences between $T$. cordata and $T$. tomentosa, between $T$. platyphyllos and T. tomentosa and also among individuals of the same species in different traffic conditions in the same sampling period, were also highly significant. The lowest average accumulation during the growing season was recorded in the area with low traffic for T. tomentosa $(7.03 \mathrm{mg} / \mathrm{kg} \mathrm{Pb}-\mathrm{T} / \mathrm{AL})$ and the highest average accumulation was recorded in the area with the heaviest traffic for $T$. tomentosa $(17.83 \mathrm{mg} / \mathrm{kg} \mathrm{Pb}-\mathrm{T} / \mathrm{AR})$. Similar results were reported in various deciduous broadleaves: Quercus ilex (Alfani et al., 1996), Tilia spp. and Aesculus hippocastanum (Sućur et al., 2010), Acer platanoides, Aesculus hippocastanum and Betula pendula (Petrova et al., 2014), in which $\mathrm{Pb}$ was mainly accumulated due to the traffic intensity in the sampling location. Recent studies indicated that $\mathrm{Pb}$ has exceeded the maximum admitted level in ClujNapoca, Romania, under different traffic conditions, in the leaves of Acer platanoides, A. pseudoplatanus, Aesculus bippocastanum, Betula pendula, Juglans regia, Picea pungens var. glauca, Picea abies, Pinus nigra, Tilia cordata, Robinia pseudoacacia, Thuja occidentalis (Viman et al., 2011).

There were highly significant differences in $\mathrm{Pb}$ seasonal accumulation not only among all species of lime-tree studied but also among individuals within species, in the same traffic conditions and different sampling periods (seasonal accumulation). The $\mathrm{Pb}$ accumulation at the end of the growing season is high for all species and locations (minimum $7.4 \mathrm{mg} / \mathrm{kg}$ $\mathrm{Pb}-\mathrm{T} / \mathrm{AL} / \mathrm{A}$ and maximum $17.84 \mathrm{mg} / \mathrm{kg} \mathrm{Pb}-\mathrm{T} / \mathrm{AR} / \mathrm{A})$. The highly significant differences in $\mathrm{Pb}$ accumulation among the lime-tree species studied at the end of the growing season may be in relation with leaf shape and size (Hovmand et al., 2000; Alfani et al., 1996). Seasonal accumulation of other potential toxic metal, arsenic (As), in the leaves of Tilia spp. and Aesculus bippocastanum was reported in the Belgrade urban area (Sućur et al., 2010). However, As and $\mathrm{Pb}$ do not have any physiological function in plants and could be toxic (Adriano, 1986; Madejón et al., 2004). The seasonal accumulation of $\mathrm{Pb}$ may be explained as a detoxification process by passive sequestration of toxic metals in senescing foliage (Aznar et al., 2009 from Popovic et al., 2010). Significant seasonal accumulations of heavy metals in the leaves of Tilia spp. were reported (Bargagli, 1998; Piczak et al., 2003; Tomaševic et al., 2004b; Anicic et al., 2011).

Table 2. Multiple comparisons of the average Pb content for Tilia spp. leaves at the beginning and at the end of growing season, in areas with different pollution level from Western Romania

\begin{tabular}{|c|c|c|c|c|c|c|c|c|c|c|c|c|c|}
\hline $\begin{array}{c}\text { Dataset } * \mathrm{~Pb} \\
\text { average } \\
\text { content } \\
\text { ( } \mathrm{mg} / \mathrm{kg} \text { of } \\
\text { dry material) }\end{array}$ & $\begin{array}{c}\mathrm{C} / \mathrm{AL} / \mathrm{M} \\
0.06850\end{array}$ & $\begin{array}{l}\mathrm{C} / \mathrm{AL} / \mathrm{A} \\
15.36400\end{array}$ & $\begin{array}{l}\mathrm{C} / \mathrm{II} / \mathrm{M} \\
0.27650\end{array}$ & $\begin{array}{c}\text { C/II/A } \\
15.95800\end{array}$ & $\begin{array}{c}\mathrm{C} / \mathrm{B} / \mathrm{A} \\
13.72000\end{array}$ & $\begin{array}{c}\mathrm{P} / \mathrm{AL} / \mathrm{M} \\
0.17130\end{array}$ & $\begin{array}{l}\mathrm{P} / \mathrm{AL} / \mathrm{A} \\
10.45400\end{array}$ & $\begin{array}{c}\mathrm{P} / \mathrm{M} / \mathrm{A} \\
15.08000\end{array}$ & $\begin{array}{c}\mathrm{P} / \mathrm{B} / \mathrm{A} \\
14.68600\end{array}$ & $\begin{array}{c}\mathrm{T} / \mathrm{AL} / \mathrm{M} \\
0.36310\end{array}$ & $\begin{array}{l}\text { T/AL/A } \\
7.4000\end{array}$ & $\begin{array}{c}\text { T/AR/M } \\
0.01280\end{array}$ & $\begin{array}{l}\text { T/AR/A } \\
17.84300\end{array}$ \\
\hline \multicolumn{14}{|l|}{$\mathrm{C} / \mathrm{AL} / \mathrm{M}$} \\
\hline C/AL/A & 0,000017 & & & & & & & & & & & & \\
\hline $\mathrm{C} / \mathrm{II} / \mathrm{M}$ & 0.699553 & 0.000016 & & & & & & & & & & & \\
\hline $\mathrm{C} / \mathrm{II} / \mathrm{A}$ & 0.000011 & 0.239103 & 0.000017 & & & & & & & & & & \\
\hline $\mathrm{C} / \mathrm{B} / \mathrm{A}$ & 0.000017 & 0.002576 & 0.000024 & 0.000074 & & & & & & & & & \\
\hline $\mathrm{P} / \mathrm{AL} / \mathrm{M}$ & 0.838130 & 0.000017 & 0.834406 & 0.000017 & 0.000021 & & & & & & & & \\
\hline $\mathrm{P} / \mathrm{AL} / \mathrm{A}$ & 0.000024 & 0.000024 & 0.000046 & 0.000021 & 0.000052 & 0.000029 & & & & & & & \\
\hline $\mathrm{P} / \mathrm{M} / \mathrm{A}$ & 0.000017 & 0.572612 & 0.000017 & 0.100915 & 0.010700 & 0.000016 & 0.000029 & & & & & & \\
\hline $\mathrm{P} / \mathrm{B} / \mathrm{A}$ & 0.000016 & 0.206397 & 0.000021 & 0.020511 & 0.056919 & 0.000017 & 0.000046 & 0.434093 & & & & & \\
\hline $\mathrm{T} / \mathrm{AL} / \mathrm{M}$ & 0.599614 & 0.000017 & 0.863366 & 0.000016 & 0.000029 & 0.722013 & 0.000052 & 0.000021 & 0.000024 & & & & \\
\hline T/AL/A & 0.000029 & 0.000021 & 0.000052 & 0.000017 & 0.000046 & 0.000046 & 0.000108 & 0.000024 & 0.000029 & 0.000108 & & & \\
\hline $\mathrm{T} / \mathrm{AR} / \mathrm{M}$ & 0.911895 & 0.000011 & 0.638529 & 0.000011 & 0.000016 & 0.768870 & 0.000021 & 0.000017 & 0.000017 & 0.543310 & 0.000024 & & \\
\hline $\mathrm{T} / \mathrm{AR} / \mathrm{A}$ & 0.000011 & 0.000055 & 0.000017 & 0.000380 & 0.000024 & 0.000011 & 0.000017 & 0.000046 & 0.000029 & 0.000017 & 0.000016 & 0.000011 & \\
\hline $\mathrm{T} / \mathrm{C} / \mathrm{A}$ & 0.000021 & 0.000042 & 0.000029 & 0.000024 & 0.140051 & 0.000024 & 0.000110 & 0.000147 & 0.001351 & 0.000046 & 0.000052 & 0.000017 & 0.000021 \\
\hline
\end{tabular}

(Duncan test, bold marked effects are highly significant at $\mathrm{p}<0.0001$; italic marked effects are significant at $\mathrm{p}<0.05$ )

${ }^{*}$ *pecies (C - T. cordata; P - T. platyphyllos; T - T. tomentosa); locations (AL - Albinelor Street, Timişoara; II - I. I. de la Brad Street, Timişoara; AR - Airport, Timişoara; M - Borlova Forest; B - Borlova village; C - Căvăran Forest); sampling data (M - May; A - August)

\section{Conclusion}

Lime tree species appeared to be highly resistant to abiotic and biotic stress. No major pest or disease of Tilia spp. was reported in the recent period in Western Romania. Our results indicated that the $\mathrm{Pb}$ content significantly increased during the growing season from very low values in May to much higher values in August in Tilia spp. leaves for all individuals studied and locations. The highest $\mathrm{Pb}$ content values were recorded for $T$. tomentosa in the area with the heaviest traffic and towards the end of the growing season. This supports the hypothesis of a self-detoxification mechanism of Tilia spp. by leaves fall. Other heavy metals analyzed $(\mathrm{Cr}, \mathrm{Cu}, \mathrm{Fe}, \mathrm{Mn}, \mathrm{Ni})$ did not have regular accumulation in leaves during the growing season, probably due to different metabolic aspects. In spite of the increasing tendency to introduce exotic tree species in green areas, in the context of climate change, Tilia spp. are highly recommended to be used in urban landscapes. These tree species showed a high potential to improve the urban environment and also have an important ornamental, ecological and socio-economic value.

\section{Acknowledgments}

This paper was presented at the International Symposium "Forest and Sustainable Development", Brașov, Romania, 24-25 October 2014, and published with the support of the European Social Fund, Human Resources Development Operational Programme 2007-2013, project no. POSDRU/159/1.5/S/132765. 


\section{References}

Adriano DC (1986). Trace elements in the terrestrial environment. Springer Press, New York, $533 \mathrm{p}$.

Aničić M, Spasić T, Tomašević M, Rajšić S, Tasić M (2011). Trace elements accumulation and temporal trends in leaves of urban deciduous trees (Aesculus hippocastanum and Tilia sp.). Ecological Indicators 11(3):824-830.

Alfani A, Batroli G, Rutigliano FA, Maisto G, Virzo De Santo A (1996). Trace metal biomonitoring in the soil and the leaves of Quercus ilex in the urban area of Naples. Biological Trace Element Research 51 (1):117-131.

Aloway BJ (1995). Soil process and the behavior of heavy metals, p. 11-38. In: Alloway BJ (Ed). Heavy metal in soils, Second edition, Blackie Academic Professional an import from Chapman \& Hal.

Bargagli R (1998). Trace elements in terrestrial plants. An ecophysiological approach to biomonitoring and biorecovery. Ed. Springer-Verlag, Berlin, $324 \mathrm{p}$.

Baycu G, Tolunay D, Ozden H, Gunebakan S (2006). Ecophysiological and seasonal variation in $\mathrm{Cd}, \mathrm{Pb}, \mathrm{Zn}$ and $\mathrm{Ni}$ concentrations in the leaves of urban deciduous trees in Istanbul. Environ Pollut 143:545-554.

Blench R, Spriggs M (1999). Archaeology and language: language change and cultural transformation. Ed. Routledge, $253 \mathrm{p}$.

Bolea V, Chira D (2005). The Atlas of pollution in Braşov. Ed. Silvodel, Braşov, $140 \mathrm{p}$ (in Romanian).

Braun M, Margitai Z, Tóth A, Leermakers M (2007). Environmental monitoring using linden tree leaves as natural traps of atmospheric deposition: A pilot study in Transylvania, Romania. AGD Landscape and Environment 1(1):24-35.

Chira D, Tăut I, Chira F (2000). Diseases. In: Simionescu A, Mihalache G (Eds). Forest protection. Ed. Muşatinii, Suceava pp 460-613 (in Romanian).

Ciupa V, Radoslav R, Oarcea C, Oarcea Z (2005). The green Timişoara - The green areas of Timişoara. Ed Marineasa, Timişoara, 216 p (in Romanian).

Dănescu F, Mihăilă E, Costăchescu C, Drăgan D (2011). Management measures of forest areas in the plains region at risk of flooding and prolonged water stagnation. Ed. Silvică, Bucureşti, $426 \mathrm{p}$ (in Romanian).

Eliade M (1995). From Zalmoxis to Ginghis-han. Ed Humanitas, Bucureşti, $270 \mathrm{p}$ (in Romanian).

Evseev I (2001). The encyclopedia of cultural symbols and archetypes. Ed Amarcord, Timişoara, $230 \mathrm{p}$ (in Romanian).

Fineschi S, Salvini D, Taurchini D, Carnevale S, Vendramin GG (2003). Chloroplast DNA variation of Tilia cordata. Can J Forest Res 33(12):2503-2508.

Fricke O, Kurschner K, Rohrig E (1980). Undreplanting in a Quercus robur stand. Forstarchiv 11(51):228-232.

Gregger M (1999). Metal availability and bioconcentration in plants, p.1-27. In: Prasad MNV, Hegemeyer J (Eds). Heavy metal Stress in Plants. From Molecules to Ecosystem. Springer-Verlag, Berlin.
Halajová D, Halaj P (2013). Tree survey and proposals for urban tree management in a residential complex in Nitra city, Slovakia, Journal of International Scientific Publications: Ecology and Safety 8:400-408.

Hovmand MF, Nielsen SP, Johnsen I (2009). Root uptake of lead by Norway spruce grown on $210 \mathrm{~Pb}$ spiked soils. Environ Pollut 157:404-409.

Iordache V (2009). Heavy metals ecotoxicology in Danube floodplain. Ars Docendi, Bucureşti, 340 p (in Romanian).

Ivănescu D, Rubțov Ş, Bândiu C (1966). The Lime-tree. Ed. AgroSilvică, București, $269 \mathrm{p}$ (in Romanian).

Khavaninzadeh AR, Veroustraete F, Buytaert JAN, Samson R (2014). Leaf injury symptoms of Tilia sp. as an indicator of urban habitat quality. Ecol Indic 4:58-64.

Kovács M, Podani I (1986). Bioindicators. A short review on use of plants as indicators of heavy metals. Acta Biol Hung 37:1929.

Madejón P, Marańón T, Murillo JM, Robinson B (2004). White poplar as a biomonitor of trace elements in contaminated riparian forests. Environ Pollut 132:145-155.

Matula R, Svátek M, Kůrová J, Úradníček L, Kadavý J, Kneifl M (2012). The sprouting ability of the main tree species in Central European coppices: implications for coppice restoration. Eur J Forest Res 131(5):1501-1511.

McDonald AG, Bealey WJ, Fowler D, Dragosits U, Skiba U, Smith RI, Donovan RG, Brett HE, Hewitt CN, Nemitz I, (2007). Quantifying the effect of urban tree planting on concentrations and depositions of PM10 in two UK conurbations. Atmos Environ. 41(38):8455-8467.

Neville-Jones G (1968). Taxonomy of American species of linden (Tilia). Illinois Biological Monographs (39), University of Illinois, $182 \mathrm{p}$.

Nowak DJ, Crane DC, Stevens JC (2006). Air pollution removal by urban trees and shrubs in United States. Urban Forestry and Urban Greening 4:115-123.

Nowak DJ, Hoehn R, Crane DE (2007). Oxygen production by urban trees in the United States. Arboriculture and Urban Forestry 33(3):220-226.

Oroian I, Viman O, Mihăiescu T, Odagiu A, Paulette L (2012). The air microelemental pollution and trees health status. A case study: quantification of air pollution with $\mathrm{Pb}$, using trees as bioindicators. Bulletin UASVM Horticulture 69(2):461-463.

Piczak K, Lesniewicz A, Zyrnicki W (2003). Metal concentrations in deciduous tree leaves from urban areas in Poland. Environ Monit Assess 86:273-287.

Pigott CD (1991): Biological flora of the British Isles Tilia cordata (Miller) (T. europaea L. proparte, T. parvifolia Ehrh. Ex Hoffm., T. sylvestris Desf., T. foemina folio minore Bauhin). Journal of Ecology 79:1147-1207.

Pilegaard K, Johnsen I (1984). Heavy metal uptake from air and soil by transplanted plants of Achillea millefolium and Hordeum vulgare. Ecological Bulletin 36:97-102. 
264

Popović D, Todorović D, Aničić $M$, Tomašević $M$, Nikolić J, Ajtić J (2010). Trace elements and radionuclides in urban air monitored by moss and tree leaves, pp. 117-142. In: Air quality. Kumar A (Ed), Sciyo.

Radoglou K, Dobrowolska D, Spyroglou G, Nicolescu VN (2009). A review on the ecology and silviculture of limes (Tilia cordata Mill., Tilia platyphyllos Scop. and Tilia tomentosa Moench.) in Europe. Die Bodenkultur 60(3):7-17.

Serbula SM, Kalinovic TS, Ilic AA, Kalinovic JV, Steharnik MM (2013). Assessment of airborne heavy metal pollution using Pinus spp. and Tilia spp. Aerosol and Air Quality Research 13:563-573.

Simionescu A, Chira D, Mihalciuc V, Ciornei C, Tulbure C (2012). The health of Romanian forests 2001-2010. Ed. Muşatinii, Braşov, 600 p (in Romanian).

Sjöman H, Oprea A (2010). Potential of Tilia tomentosa Moench. for use in urban environments in north-west Europe, based on habitat studies in North-East Romania and the Republic of Moldova. Ekológia 29(4):360-372.

Sjöman H, Östberga J, Bühler O (2012). Diversity and distribution of the urban tree population in ten major Nordic cities. Urban Forestry and Urban Greening 11:31-39.

Soukand R, Quave CL, Pieroni A, Pardo-de-Santayana M, Tardío J, Kalle R, Łuczaj L, Svanberg I, Kolosova V, Aceituno-Mata L, Menendez-Baceta G, Kołodziejska-Degórska I, Pirożnikow E, Petkevičius R, Hajdfari A, Mustafa B (2013). Plants used for making recreational tea in Europe: a review based on specific research sites. Journal of Ethnobiology and Ethnomedicine 9(1):58.

Sućur KM, Aničić MP, Tomašević MN, Antanasijević DV, PerićGrujić AA, Rristić MDJ, (2010). Urban deciduous tree leaves as biomonitors of trace element (As, V and Cd) atmospheric pollution in Belgrade. Serbia J Serb Chem Soc 75(10):14531461.

Jensen SJ (2003). EUFORGEN Technical Guidelines for genetic conservation and use for lime (Tilia spp.). International Plant Genetic Resources Institute, Rome.
Šomšak L, Kromka M, Antoni J, Žarnovičan H (2007). Heavy metals in soils of secondary spruce forests in the Slovenské Rudohorie Mountains, and their accumulation by some trees. Ekológia 26(4):437-444.

Şofletea N, Curtu L (2007). Dendrology. Ed Univ “Transilvania”, Braşov, 418 p (in Romanian).

Tomaševic M, Anicic M, Jovanovic L, Petric-Grujic J, Ristic M (2004a). Decidous tree leaves in trace elements biomonitoring: A contribution to methodology. Ecol Indic 11:1689-1695.

Tomaševic M, Rajšic S, Dordevic S, Tasic DM, Krstic J, Novakovic V (2004b). Heavy metals accumulation in tree leaves from urban areas. Environ Chem Lett 11(2):151-154.

Țenche-Constantinescu AM (2011). The study of groundwater quality in Timişoara periurban area. BUASVM Timişoara, PhD Diss. 326 p (in Romanian).

Velickovic MV (2010). Reduced developmental stability in Tilia cordata leaves: effects of disturbed environment. Period Biol 112(3):273-281.

Viman O, Oroian I, Mihaiescu T, Odagiu A, Covrig I (2011). Study concerning the level of pollution with heavy metals of forestry species from Cluj-Napoca Town. Bulletin UASVM Agriculture 68(2):153-157.

Zare H, Amini T, Assadi M (2012). A review of the genus Tilia L. (Tiliaceae) in Iran, new records and new species. Iran J Bot 18:175-190.

Zuparko RL, Dahlsten DL (1994). Host plant resistance and biological control for linden aphids. Journal of Arboriculture 20(5):278-281.

Environment Protection Agency, Timişoara, Romania (2014). The environmental status in Timiş county, May-July 201422 p, http://www.anpm.ro/web/apm-timis/rapoarte-lunare1 (accessed in 7 January, 2015, in Romanian). 